\title{
The learning process of the use of technologies as practice: An ethnomethodological approach in travel agencies
}

\author{
processo de aprendizagem do uso de tecnologias como prática: \\ Uma abordagem etnometodológica em agências de viagens
}

\section{El proceso de aprendizaje del uso de tecnologías como la práctica: Un enfoque etnometodológico en agencias de viajes}

\author{
Marcelo de Souza Bispo ${ }^{1}$ \\ Arilda Schmidt Godoy ${ }^{2}$
}

\begin{abstract}
Technology and the internet are transforming social relations and the way of working and organizing of organizations in different markets. In this way, travel agencies were also impacted by these changes and are facing a time of transition and rediscovery. This paper uses the Practice-based studies (Gherardi, 2006) and ethonomethodology (Garfinkel, 2006) to understand the impact of technology in this kind of organization through a qualitative empirical research. The aim of the paper is to comprehend the process of learning that permeates the use of information and communication technologies, particularly the internet, as work practice in a travel agency and how it can reassemble this kind of organization. As main findings, the paper discusses the use of information and communication technologies as practice and their impact in the learning, knowing and organizing processes inside three travel agencies of a Brazilian company.
\end{abstract}

Keywords: Learning; Organizing; Technology as practice; Ethnomethodology; Travel agencies.

Resumo: Tecnologia e internet estão transformando as relações sociais e as formas de trabalhar e organizar de organizações em diferentes mercados. Desta forma, as agências de viagem também foram impactadas por essas mudanças e estão enfrentando um momento de transição e de redescoberta. Este trabalho utiliza os Estudos Baseados em Prática (Gherardi, 2006) e a etnometodologia (Garfinkel, 2006) para entender o impacto da tecnologia neste tipo de organização através de uma pesquisa empírica qualitativa. $O$ objetivo do trabalho é compreender o processo de aprendizagem que permeia o uso de tecnologias de informação e comunicação, particularmente a Internet, como prática de trabalho em uma agência de viagens e como ela pode influenciar esse tipo de organização. Como principais conclusões, $o$

\footnotetext{
${ }^{1}$ Doutor em Administração pela Universidade Presbiteriana Mackenzie. Bacharel em Turismo pela Universidade Metodista de São Paulo. Professor Adjunto da Universidade Federal da Paraíba, Centro de Ciências Sociais Aplicadas, Departamento de Administração. E-mail: marcelodesouzabispo@gmail.com

${ }^{2}$ Doutora em Educação pela Universidade de São Paulo. Professora do PPGA - Mackenzie. Pesquisadora do Núcleo de Pesquisa e Formação em Administração (NUPES).E-mail: arilda-godoy@uol.com.br
} 
artigo discute o uso das tecnologias da informação e comunicação como prática e seu impacto na aprendizagem assim como nos processos de conhecer e organizar dentro de três agências de viagens de uma empresa brasileira.

Palavras-chave: Aprendizagem; Processo de organizar; Tecnologia como prática; Etnometodologia; Agências de viagens.

Resumen: Tecnología e Internet están transformando las relaciones sociales y la forma de trabajo y organización de las organizaciones en los diferentes mercados. De esta manera, las agencias de viajes también se vieron afectados por estos cambios y se enfrentan a un momento de transición y el redescubrimiento. Este artículo utiliza los Estudios Basados en Práctica (Gherardi, 2006) y etnometodología (Garfinkel, 2006) para comprender el impacto de la tecnología en este tipo de organización a través de una investigación empírica cualitativa. El objetivo de este trabajo es comprender el proceso de aprendizaje que impregna el uso de las tecnologías de la información y la comunicación, en particular la Internet, como práctica del trabajo en una agencia de viajes y cómo se puede volver a influenciar este tipo de organización. Como principales conclusiones, el documento analiza el uso de tecnologías de la información y la comunicación como práctica y su impacto en el aprendizaje, el conocimiento y la organización de los procesos dentro de tres agencias de viajes de una empresa brasileña.

Palabras clave: Aprendizaje; El proceso de organizar; Tecnología como práctica; Etnometodologia; Agencias de viajes.

\section{INTRODUCTION}

Travel agencies are facing a time of transition and rediscovery. This condition occurs, in particular, due to the growing advancement of technologies available for organizational management and, more specifically, due to the use of information and communication technologies that require new knowledge and ways of learning that are not necessarily bound to methodologies not supported by formal classrooms and training rooms. This is a tacit and aesthetic process in which solutions developed in the chain of travel are increasingly dependent on the process of learning and knowing-in-practice.

In this context the use of technologies by the customers and the travel agents, especially those that can facilitate the interaction by internet are transforming the way of working and organizing in travel agencies, beyond changing some procedures in workplace.

Tourism is an important social and economic activity, according to World Tourism Organization - UNWTO - the travelling numbers in development and emerging countries arouse in 2010 and contributed to overlap the world crisis (UNWTO, 2010). In this way, travel agencies, as part of this market, have a large contribution to tourism development. However, there are not many researches whose publishing are focusing tourism organizations, especially, forms of learning, knowing and organizing in travel agencies (Valtonen, 2009). As organizations that are reassembling due to the impact of new technologies in the way of organizing, knowing and doing, this paper attempts to fulfill the gap of managent research in tourism organizations, principally related with theoretical and methodological frameworks alternatives in the themes of 
learning and knowing using Practice-based studies (PBS) and ethnomethodology. In other words, it is a new way to see and understand this kind of organization.

In this way, the paper aims to comprehend the process of learning that permeates the use of information and communication technologies, particularly the internet, as work practice in a travel agency and how it can reassemble this kind of organization.

Thus, this new way of organizing travel agencies influenced by the use of technologies as practice by the customers and the travel agents imply in a dynamic knowing-in-practice travel activity that change the notion of the boundaries in this kind of organization. We must try to understand how people learn from each other in everyday life, from social interactions that transcend the formal processes used by organizations. This effort requires looking at the organizations as symbolic and aesthetic fields in which people live in constant interaction mediated by language building meaning (Hatch, \& Yanow, 2003) and sensible knowledge (Strati, 2007,2009 ) to their everyday activities. According to this perspective it is possible to understand the organization, specially travel agencies, as a place of learning and knowing permeated by negotiation and continued exchange, nowadays highly influenced by the impacts of the technologies, principally when we focus their use. In this perspective, this paper adopted Practice-based studies (Gherardi, 2006; Nicolini, Gherardi, \& Yanow, 2003) and ethnomethodology (Coulon, 2005; Garfinkel, 2006) as principal theoretical and methodological approach. Practice-based studies is seen as an option to debate, discuss and understand the collective and non-formal learning processes in organizations (Gherardi, 2001, 2006; Nicolini, Gherardi, \& Yanow, 2003) .

The empirical research was conducted in three travel agencies of the same company in São Paulo - Brazil that offers travel services for leisure and business. Anchored in ethnomethodology as methodological approach we used participant observation, informal conversation, field notes and recordings of audio and video of daily work activities. The interpretation process of the data was an effort to find practices that emerged from the field (Gherardi, 2006; Nicolini, 2009; Ten Have, 2004) and can represent the way of learning, knowing and organizing of the travel agency company. To do so, during the collect of the data we pointed out some activities that could represent a practice and in the end of the field period we analyzed the whole "possible" practices to elect the most relevant one that for us, in fact, better represented the studied organization. From this point we started to interpret and comprehend the use of technology as a practice related with learning, knowing and organizing.

In order to achieve the purpose of this paper, we start our theoretical discussion with some epistemological and ontological assumptions about organizations, specially the small tourism ones. After, we present the Practice-based studies and ethnomethodology. Later, there is the methodological description, and the reflections and interpretations on the results. Finally, we point out some remarks. 


\section{EPISTEMOLOGICAL AND ONTOLOGICAL ASSUMPTIONS ABOUT ORGANIZATIONS}

The demands of organizations for innovation and change in order to survive in the hypercompetitive environment suggest new ways of thinking "what is" to learn and to know, that seem to go beyond what is available in books, textbooks, classrooms and training rooms in the companies.

In the context of tourism organizations, the relationship between the process of organizing and the process of learning and knowledge generation is also something latent, especially on those small and medium businesses. However, according to Valtonen (2009) this issue has been receiving little attention from the academic areas of management and tourism. The author points out that micro and small tourism enterprises have a range of possibilities to be investigated and epistemological qualities that enable relevant research, unlike what occurs predominantly in the research on the business administration field, where such organizations are seen as displaying a "knowledge vacuum" or being unable to adopt efficient systems of knowledge management. In this sense Valtonen (2009) points out that small companies in the tourism sector contribute to a distinct way of knowledge generation, particularly when the focus is on a more practical knowledge

The author regards some points as relevant characteristics of this type of organization, such as cash limitations, management carried out by owners, the belief in the informal mechanisms of control, besides the fact that people perform multiple tasks. Thus, these organizations are described as businesses intensely based on the interaction with customers that is configured in a specific space-time relationship with respect to the pace and practice. In line with Czarniawska (2008), Valtonen (2009) points out that to define organizations, including small tourism businesses, is quite complex and that it is also difficult to identify where they "finish" and consumers "start", especially when focusing on the technological influences.

These attributes configure these organizations in special and unique conditions to a practice-based knowledge. These characteristics indicate / suggest that the learning processes in small tourism businesses are based in the everyday interactions of people, places and the material world. To Valtonen (2009), this occurs because the tourism work is, mainly, driven by the interactions that make up the nature of this type of work. The author argues that institutionalization of knowledge in small tourism businesses is based on a set of local cultural, social, aesthetic, emotional and symbolic attributes which are present in the learning and create specific knowledge that people use to deal with the most varied situations of their everyday life. Thus, these organizations must be understood and investigated with lenses different from the ones usually used for large companies.

Hatch (1997) points out that understanding the organization is essential for those seeking to act within them, whether with management or research purposes. According to her, organizational dynamics is the background for understanding organizational actions, i.e. organizational acting is directly related to the way in which organizations are constituted and 
negotiate their daily lives. According to Sandelands and Srivatsan (1993), the major problem in studying organizations is the difficulty in defining them, for the word "organization" refers to something that cannot be seen or confirmed as an object, not least because, in many circumstances, its limits cannot be delineated, which creates difficulties in description and / or identification.

On dealing with organizations using the concepts of organizational texture and organizing processes, Gherardi $(2006,2009 b)$ emphasizes that organizations are the result of their practices that originate from a process of sharing inter subjectivities in which aesthetic judgment is a reference to the organization acting. To the author, most relevant is the process of organizing without, necessarily, assuming the organization as a separate system. Gherardi (2006) understands the organizational texture as the connection between social actors in the action, that is, organizations are formed from the collective practices of the actors and the set of practices that forms the texture. So, is the organizational texture that allows the creation of identity for the organization.

As much as people seek to create models of stable organizations with well-defined spatial and action limits, organizations are always the result of everyday interaction and intersubjectivity established between their members from their practices. Czarniawska (2008) points out that a lot of what there is in organizations is not directly accessible by formal tools - reports, manuals, official speeches, etc. - because there are many "rules" and agreements that are tacitly internalized (taken-for-granted).

To Sandelands and Srivatsan (1993) the best way to understand an organization is by experiencing it. According to these authors there is a lack of studies seeking to discuss what organizations are empirically and, many times, to meet the need of performing organizational studies, metaphors are created to contextualize and explain organizations in a idealized way. The use of metaphors is criticized by the authors because it avoids direct experiences in organizations, replaced by the metaphors, which creates an organization detached from reality. The argument of experiencing organizations is aligned with the premise that "the way you see something determines what you see", i.e., to Sandelands and Srivatsan (1993) a highly aesthetic theory. In our understanding, the authors' criticism is valid when a metaphor is created to substitute an experience; however, the metaphor is welcome when used to verbalize a real experience bearing strong tacit and aesthetic content.

To Czarniawska (2008) is also necessary to understand that organizations are not necessarily made only by social actors who share the same physical space, i.e., it is necessary to consider that not all interactions require people to be physically present, or still, to share the same temporality. Thus, interactions mediated by technology, synchronously or asynchronously, in the same physical space, or in different spaces, should be taken into consideration when we try to understand what organizations are nowadays.

The impact of information and communication technologies (ICT) in organizations involves a redesign of the workspace, where knowledge is dispersed and fragmented among people, 
artifacts, organizational rules and habits, so that they can be supported by an infrastructure. This way, remote working requires the development of skills based on common sense resources for acting in this fragmented space of knowledge (Bruni, Gherardi, \& Parolin, 2007). Recognizing that organizations are composed by human and nonhuman elements leads to the understanding of the workplace as fragmented systems of knowledge (ibid.) in which people, symbols, and technologies work together to build and rebuild social understanding and organizational action.

Understanding the use of technologies as social practice (Suchman et al., 1999) deepens the understanding of organizations as social contexts since technology currently influences the shape of organizational processes and the way of seeing and understanding organizations. Put in another way, technologies change the ways people interact and experience their daily life, within and outside the organizational context, which forces us to consider it as part of the act of organizations.

\section{PRACTICE-BASED STUDIES AND ETHNOMETHODOLOGY}

Gherardi (2006) points out that the emphasis on PBS is on recognizing social sciences as promoter of the discussion about the limitations of rationality and questioning of the functionalist paradigm in organizational studies. The author suggests that this approach opens the possibility to understand that it is possible to do science without necessarily seeking generalizations and deal with the phenomena in a situated way, whereas the temporality and historicity have significant value to a better understanding of social worlds. Also according to the author, this way of thinking organizations value what Gherardi puts as knowing-in-practice, i.e. it means that knowledge is situated as a social, human, material, aesthetic process, as well as emotional and ethical. It also means that knowledge is built upon the practices, in a process that associates knowing and doing.

In this sense, practice is "a figure of discourse that allows the processes of 'knowing' at work and in organizing to be articulated as historical processes, material and indeterminate" (Gherardi, 2000, pp. 220-221). Every individual practice is situated in a wide range of practices which spreads over all directions from the individual to the organizational and institutional, as well as any other complex system. Here, learning is not understood as individual, group and organizational distinct processes, but as a single process in which every single one is covered simultaneously. The field of practice is understood as a composition of interconnected activities which are in constant pattern change (Gherardi, 2006).

The concept of practice has arisen within the sociological traditions of learning that emphasizes a situated understanding of the learning process highlighting the importance of context in this process.

Gherardi (2009a, 2009b) considers practices as the ways of doing of a society, so, through reflexivity, practices produce and reproduce society, they are collective constructions situated and recognized only within inter subjectivity. For the author (2009b: 536), "practice is an analytic 
concept that enables interpretation of how people achieve active being-in-the-world". Thus, a practice is not recognized outside the meaning created from inter subjectivity. So, the understanding of practice is not synonymous with habit or routine activities in isolation, but a recurring social pattern sustained by the actions played within a society (Gherardi, 2009b).

Gherardi (2006) points out that a straightforward definition of practice involves a reductionism that the concept does not have, however, the author, from its definition, emphasizes that it is necessary to search the grounds that are basis for understanding the practice. Therefore, using as reference phenomenological and ethnomethodological assumptions, Gherardi (2006, p. 34) defines a practice as a "relatively stable in time and socially recognized, of ordering heterogeneous items into a coherent set". From this definition, the author refers to four key features to the understanding of the term practice.

First, she emphasizes the holistic and qualitative aspect of a practice by highlighting it as a set of activities that have meaning and become recognized as a unit. Also, it is important to emphasize that this set of activities can only form its meaning in the context of a recognized and situated action by certain agents involved in it. Second, she highlights the relationship between practice to temporality. For the author, practices must be repeated many times to be socially recognized as a customary way of doing things. However, the reproduction of the social world does not happen mechanically, but may be understood as a process that while maintaining the original shapes, allows the simultaneous implementation of changes. In this sense, practices have a history and persist over time despite their continuous adaptation to circumstances. As a third characteristic, the author emphasizes that practices need to be socially recognized and presuppose the existence of an institutional system that gives support to the rules that guide such practices. Finally, one can say that they are a way of organizing the world. When the practices are performed they introduce a certain organization of human and non-human elements, yet fragile, temporary and constantly threatened by the disorder, become part of a network of practices, anchored to each other.

In alignment with PBS, ethnomethodology is presented as a possibility for investigation of situated and naturalistic processes of learning, knowing and practices. Ten Have (2004) says that, in ethnomethodology, facts are seen as being produced in the members and by the members themselves during practical activities, i.e., the interest of ethnomethodological research is the understanding of everyday life.

Ethnomethodology has as main reference and founder of the movement the sociologist Harold Garfinkel, who has developed his ideas from elements found in symbolic interactionism, on the Parsons work and the phenomenology of Husserl and Schutz. Another significant influence is the legacy of Wittgenstein in relation to linguistic games. His most famous work is Studies in Ethnomethodology, published in 1967 (Coulon, 2005).

For Garfinkel, Sociology should not be understood as a positivistic science in which facts, according to Durkheim, are established a priori by a stable structure independently of the history and in an objective manner. Garfinkel proposed a sociology that has an interpretive stance that 
valued subjectivity in which describing a situation is to build it. In this line of thought, sociology considers social acts as practical achievements that do not constitute a stable object, but a product of the ongoing activity of people who apply their "know-how" (knowing and doing), and its procedures and rules of conduct. In other words, it is a profane sociology (Coulon, 2005).

The term ethnomethodology refers to "everyday methodology" in which etno means member of a group or of the group itself and methodology refers to the members methods. Thus, ethnomethodology regards to the actual situated practices (Psathas, 2004).

Maynard and Clayman (1991) suggest that the basis of ethnomethodology is in the practical activities through which actors produce and recognize the circumstances in which they live, due to the effect that practices have for these actors. Hence, the main ethnomethodological objective is to investigate the procedures for carrying out activities, concerning about the behavior of individuals involved.

Coulon (2005, p. 32) defines ethnomethodology as "the pursuit of empirical methods used by individuals to make sense and at the same time, accomplish their daily actions: communicating, making decisions, and thinking". For him, ethnomethodology examines the beliefs and behaviors of common sense as components required to a socially organized conduct.

Coulon (2005) identifies five key concepts for the ethnomethodological research that are the ideas of practice (implementation), indexicality, reflexivity, accountability and the notion of membership.

The concept of practice or implementation, indicates that the central concern of ethnomethodology are the practical activities, natural of everyday life. It seeks to empirically examine the methods that individuals use to assign meaning and at the same time, accomplish their daily actions, be they trivial or erudite. Ethnomethodology sets out of what is known as common sense to analyze the beliefs and behaviors of members of a group, considering that all behavior is socially organized. From the idea that social reality is constantly created by actors who belong to it, ethnomethodology does not deal with the hypothesis that social actors follow rules, but is concerned to examine the methods they use to change, update and adapt such rules, interpreting and inventing constantly social reality (Coulon, 2005).

The indexicality, a technical term which has its origin in linguistics, points out that while a word has a somewhat "generic" meaning; this same word has different meaning in particular situations. Thus, to its understanding, in some cases, it is necessary to seek information beyond the simple understanding of the generic word (Coulon, 2005). This idea of indexicality indicates that a word can have an effect regardless of its conditions of use and enunciation, that is, language is a collective production that assumes different meanings depending on contextual factors such as the biography of the speaker, his immediate intention, his relationship with the hearer and their past conversations. For Garfinkel, according to Coulon (2005), natural and ordinary language, through which people express themselves in their daily lives, is deeply indexical, since to each social actor the meaning of their everyday language depends on the context in which it manifests itself. 
The concept of reflexivity is related to the "effects" of a group practice, in other words, the process of continuous construction of a group or community, through their practical activities. At the same time that they are the results of interaction between members, they imprint influences on these same individuals in the group. This is a process in which an action occurs and at the same time, produces a reaction on their creators. Reflexivity here should not be confused with reflection, because reflexivity, according to Garfinkel, refers to practices which, while describing, also constitute a social frame from which the actors express the meanings of their actions and thoughts (Coulon, 2005).

Coulon (2005) describes the idea of accountability in the context of ethnomethodology, saying that it refers to a reflective and rational condition. It is considered that activities are understandable and can be described, otherwise, is how the study group describes practical activities from the references of meaning and significance that the group itself has. Thus, accountability can be regarded as a "justification" of the group for a given activity and conduct. Romero (1991) states that accountability is the explanation that the actors use to describe, analyze, criticize, and idealize specific situations.

The fifth key concept in ethnomethodology is the conception of member. With some difference to what Parsons saw as member, the idea of an individual belonging to a group, Garfinkel believes that the member is the one who shares the language of a group. It is possible to understand that the member in Garfinkel's thinking, induces to a condition of "belonging" to the group and not just "temporarily being" in it.

These five key concepts of ethnomethodology help that the researcher, in adopting this methodology, can go out to the field with a pre-understanding that to access the desired phenomenon it is necessary to effectively participate in the group's quotidian to make it possible to understand the process of practice construction, along with their meanings. For Garfinkel, this is to practice profane sociology, i.e., the notion of profane is related to the emphasis that is given to understanding the construction of everyday life, as well as enhancing the naturalistic organization of a social group through their practices.

Ethnomethodological studies also known as workplace studies treat the employees, not the researchers, as experts. So, the search is for understanding how work gets done and how problems are detected and resolved by the employees (Rawls, 2008).

\section{METHODOLOGICAL ROUTE}

The development of this research involved an extensive bibliographic research that lasted twelve months, from May 2009 to May 2010, besides a field research in three LCA travel agencies, between April and November 2010. Three main reasons led us to choose LCA: (a) perform the research in the tourism area of business; (b) the acquaintance and good relationship we have with the owners; (c) the fact that the company which in 2005 was installed in one of partners' 
bedroom, in 2010 had already three stores, besides other businesses that have unfolded from LCA. We approached LCA with the idea of the research in the beginning of April, and both partners have welcomed the idea, and even authorized the use of the company name. However, as mentioned, for reasons of confidentiality and ethics in the research, the names of individuals were preserved in an anonymous way so that they can not be identified.

The main research method was ethnomethodology, in which the main technique used was participant observation with field notes. Besides, we also performed the analysis of documents, informal conversations and a semi-structured interview with the partners. The conduction of each technique is explained in the following text.

The field research - which is now to be reported in the first-person aiming to highlight especially the subjective experience of the author in the daily research in the three stores Vila Mariana (VM), Loja Universitária (LU), Pirituba (PI) and a corporate travel office. Most of the time I was in the VM and LU stores, once the corporate travel office was deactivated during the research and the PI store was less visited by the partners and, somehow, little influenced the actions of the company both in the question of revenues as well in the changes in procedures and processes. The VM and LU stores were also the busiest, especially VM. So, just as reference, from the approximately 250 hours of field work, I spent about 50\% in the VM store, 30\% in LU, 10\% in the corporate travel office and $10 \%$ in the PI store. The visits were not regular in frequency both in the number of hours spent in the stores, which ranged from two to eight hours, as in the number of visits and days of the week, which included weekends in the VM a PI stores that opened during these periods. The goal of scheduling the visits in this manner was to avoid that employees could create "special situations" knowing in advance of my presence.

At first, my visit to the stores aimed to "break the ice", since when I was introduced by the partners to the employees, some thought I was a consultant evaluating them, to suggest changes to the company management. However, after approximately one month of research, people began to understand my research and thereafter, the process was more friendly. In this first stage I used to just sit on some of the work positions with nothing in my hands, as if I were one of them, and observed the routine. Soon after leaving the store I made my notes in a notebook.

On the same or on the next day I would transfer the notes to a Word document. Not all the notes were transferred to the electronic journal, due to the further thoughts I had after leaving the field leading me to understand that something need not be present in the electronic document at that moment. However, to avoid losing information that might be useful at a later stage of analysis, the notebook was kept and was consulted at the time of writing the thoughts and interpretations of the practices. After the first month of field work I went to the shops with the notebook, a camera that was also a camcorder, and sometimes, a laptop, when I knew I would spend more time in the store and eventually, would need to download photos and videos and make room for new material. 
My field notes in the beginning were focused on portraying the sequence of people's work in the agency, as well as recording moments that I believed were relevant to the matter, or, how I was feeling and interpreting actions.

The photographs had as main aim to visually identify the stores by future analysis of the layouts and to perceive how the non-human elements combined with people in space. On the other hand, the videos were intended to record interactions between employees and between employees and customers.

The videos are on average five minutes in duration, but there are recordings of about fifteen minutes. In addition to the videos I also made audio recordings of meetings between the partners and employees as well as of moments of interaction between employers and employees and customers. The audio recordings were made with a cell phone to capture the interactions with a device that would not draw as much attention as the camera.

All images and sounds collected were shown to the employees of the store where I was at that time. This was a way to get closer to people and at the same time get extra information about how they felt and meant what was shown.

The informal talks took place along with participant observation as the major sources of information during the fieldwork. At first I tried to interact comparing their experiences with those I had lived in the area of tourism. This strategy has been productive as I managed to establish an empathy towards being able to talk to them about the daily work.

The documents that I most analyzed were the employees' notebooks, which served as diaries and draft books, and also, work orders, some e-mails sent and received among them and among them and clients, the web site and MSN chats. By this analysis I sought to understand how they organized their work so that it could be possible to identify the practices experienced from the interpretation of these documents in conjunction with what I observed on a daily basis.

Regarding the interviews, I made only one at the end of the fieldwork, with the presence of two partners, in which only one spoke. The main goals were to better understand the history of LCA, as well as to know what was their perception in relation to the use of technology in the travel agencies area, especially, in their company, and how these technologies influenced the choice to have some employees begin working from home (telecommuting). The semi-structured model interview sought information on LCA in relation to: the role of technology at work, how technologies are used in interactions and in everyday work, how partners evaluate the decision of the people to work from home and what they consider as success factors for the rapid growth of LCA, and finally, when the partners began working with tourism and learned to work in this segment. The interview took about thirty minutes, it was recorded but not transcribed because my goal was not to analyze the sequential construction of the text that the interview generated, but to pay attention to possible aesthetic elements present there that could contribute to my interpretation of the practices I had already observed in the field.

Before explaining the process of data analysis, it is important to note that at the beginning of my visits to the agencies, I had not selected one or more practices to be analyzed. This situation 
was adopted not by total ignorance of the field, but to apply the concept of ethnomethodological indifference which is an integral part of research of this nature. So my goal was that the practices could emerge from the field during my research process. While there is a difficulty to enter the field without knowing exactly what to analyze, the researcher has the advantage of feeling reassured that the practices identified in the field are peculiar to that research context.

To analyze the data collected during fieldwork, ethnomethodology does not adopt categorizations. The results of the survey of this nature are in the manners how a certain group builds, modifies or perpetuates a practice from a set of ordered activities. Therefore, such results are presented from the account of the practices that were identified with an emphasis in explanations of how these practices are generated, learned and shared, as well as how they are modified, when it is the case, over time. Aiming to propose a possible interpretation of the data obtained in the field, we used the five key concepts of ethnomethodology as criteria for this end.

\section{REFLECTIONS AND INTERPRETATIONS OF THE FIELD RESEARCH}

It is important to mention that the option of investigating the process of learning the practice of using technologies in LCA came after an earlier exploratory process, as recommended by experts in ethnomethodology (Ten Have, 2004, Francis \& Hester, 2004; Garfinkel, 2006; Rawls, 2008). I did not go the field with practices chosen a priori to be investigated. I spent a period of time knowing the organization, seeking, in that first moment, to identify and elect a set of activities that could suggest a practice and then investigate it. At that point of the exploratory research I relied on the concept of ethnomethodological indifference (Garfinkel, 2006). The interest in the use of technology as practice emerged after this first step on the field, since this was the practice that most caught my attention for the reasons that I report now.

When I began the research at LCA, the company had three stores and an office where worked the people who took care of corporate service, marketing and finance. However, after some time, the owners decided not to renew the lease on the office and reorganized the company. In the new model, employees who did not work directly with customers, ie, marketing and finance, started to work from home - telecommuting - and the others were transferred to one of the other three stores. During the interview with one of LCA partners, Mr. José, he commented that:

[....] driven by a modern part, or also by limitation of space and cost reduction, some employees work in the system of home office, work from home, do not have a need to to be present because ... for instance, marketing can be done from, because it is only the part of creation, monitoring social networking sites and ... the financial, he visits the units and also works at home. 
By adopting this new configuration, LCA aroused my interest in three aspects which seem relevant: (a) the premises are meant to sale and not to administrative work, (b) by placing administrative people to work from home, it is evident that the focus is in the process of selling and not in the company's management processes as a whole, (c) the reliance on technology as a means of people remote monitoring and action in the business, for communication and control.

I asked Mr. José for how long they had been organizing themselves in that way and the answer was:

We tried to do it two years ago, did not work very well, then we ended up renting an office, thinking that this was one of the problems, then we ended up with a white elephant, a comfortable super office for everyone and. .. (His cell phone rang, he was confused and did not answer) with comfort and all that ... and it does not make much sense, does not bring you income. We preferred that many employees worked from home, having access to children, having freedom, a nice time differentiation, flexibility. I think it helps in the performance, right, so there is a contract like ... verbal, where sporadically he will also be working outside working hours, and probably during work time he won't be working, depending on the demand. It is difficult to control, at LCA we do not focus much on that management of working time, we look for more productivity ... than whether the guy ... (The phone rang again and he asked for a moment, the pause lasted about five seconds) and we seek more productivity, in numbers ... It is difficult to cut cost, cost is hard to fight, specially having three stores, some people at home office, as oddly as it seems, also bring cost ... (coughs) I think today we look to have a lower cost ... isn't it ... a lower cost.

Following, I asked Mr. José how he assessed the work that people did at home that day, and he replied:

Well ... we miss the financial department ... sometimes, occasionally we wanted it to be more present, talking in the coordination controlling more closely. It is a virtue we rely one hundred percent on our financial, but at the same time, we know that is a very big risk. I think today, we ah. .. we ... believe in this quality, we trust ... but at the same time you know you're not doing the right thing. For today it is exactly what we make jokes about, "what's for today?". So, today the way we're working on is what we are financially viable, but we believe that there is a flaw in that, in the sense of having a better control about it. With respect to marketing I think it doesn't matter really ... this is that, probably, our marketer will be leaving. We're not sure whether to hire another professional or will work directly with an agency, because there is no need to stay physically in the store, but the constant visit to the stores is necessary and our clerk today, doesn't do it, she does only the basics and doesn't go out and. .. hasn't great ideas, it's also a problem. So ... we fix one side ... disturb another. Then one day we'll see if we can hit them all. 
From this information I realized that my eye should be directed to the use of technologies and the impact of these on the constitution of the practices at LCA. In particular, how employees began to develop their duties articulated as a group, although physically distant. But I also realized that even before this change, the company work he was already based on intensive use of technology so that employees could communicate with each other, with suppliers, and even with customers. The tools that make possible this form of organization and operation on the market are: electronic mail, MSN, Internet portals and GDS providers, Nextel radio, Skype phone. Mr. José said the following about this situation:

With respect to internal communication we talk all via Nextel, all shops, all people have the Nextel business, this is a huge cost right ... until we get the financial side, rethinks agent a few times but always end up choosing to leave because it is an ease. MSN wore long, even to talk with some suppliers that enable it, but lately we're cutting it for long drives because it was giving problem of private conversations e. .. spending too much time working and even generating gossip and intrigue within the company, so we decided ... take it.

As a result, Mr. José does an evaluation of the influence of technology in everyday travel agencies:

We can not see today a travel agent without the presence of technology, especially the right tools and systems, but at the same time, technology has major problems that is direct competition with the Internet. Today this technology comes straight to the final customer, passenger, now the customer has the possibility to search and often know more than you, because the technology itself. But today the tools of an agency are fully connected to the portals, the issuance of electronic tickets on time, hotel voucher, online reservation anywhere in the world, linking all of a sudden your system with the system for other companies and outside the tools today's disclosure, social networking ... then that agency today to be complete today, I think ... technology is connected to everything right! Although it had not so much technology, perhaps we had even better results. Today you gain efficiency, but at the same time, you ... lost in customization, you lose in support ... because you end up ... serving the customer ... always with the tool of technology then becomes a business rather impersonal, then this is the role, role of technology.

It is important to mention that my interview with Mr. Joseph was the end of the process of fieldwork and aimed to clarify some points that caught my attention during my presence at stores across the LCA. This allowed for a guided interview to the question of technology and at the same time, signaled the beginning of the change process regarding the use of MSN as a tool.

As a way of understanding and interpreting the use of technology as practice in LCA, I tried to emphasize the process of organizing and its relation to collective learning. Importantly, the technology as a social practice can only be understood in this way when the researcher seeks to 
establish relations of technology with its local production and use in order to understand the exchange that occurs between people, technology in use and the other artifacts in a contextualized and situated (Suchman et al., 1999).

In the case of LCA, information technology and communication have this condition when used as the glue of the organization that is spread both in physical appearance (when you consider the three stores) and in time (due to interactions via synchronous Nextel phone, MSN and Skype, as well as asynchronous electronic mail between officials, employees, suppliers and employees with customers).

The use of technology in this context embodies the LCA to all these players as an organization, however, does not have a physical space-time well-defined (Czarniawska, 2008). So we can only consider the three stores as the sole benchmark of organizational boundaries of the LCA, because we would be ignoring the interactions that are enabled by technology, especially the Internet.

These technologies make the company also presents a concrete and tangible to people, even in a virtual plane (Bruni, 2005; Nicolini, 2010a, 2010a). A good example is when this process of interaction occurs through the use of electronic portal, where the LCA is present for all the actors continuously every day of the year.

Currently, the LCA is available for interactions with its three stores in the electronic portal in the homes of people who are telecommuting, and in any other place where your employees and partners can interact using technologies to communicate, so as to meet customers and suppliers.

Valtonen (2009) argues that small organizations in the tourism field, such as the LCA, have a certain hybridity between "work", "home" and "free time", particularly when teleworking is present. Thus, the house is the workspace, and much of the knowledge developed for the execution of daily activities, makes the home a place of learning and knowledge generation for the job.

Thus, the process of learning to work is not far from learning from other activities of daily life. A good example is when a financial official of the LCA said to me, on some occasions, that the discipline of financial controls that it developed for the company is the same for the management of their household bills. In other words, intertwined with the practices and discourse to the touring professional in this context are part of a unique lifestyle.

The action of the LCA to adopt a combined model of working with some of the physical presence of employees on company property, and other configuration telecommuting strengthens the question by Czarniawska (2008) that organizational boundaries are not exactly the physical boundaries that while she has headquarters or branch, but they occur around the collective practices of its members even if they are physically distant, or even in asynchronous temporality. Hence, technology wins key role as a social actor (Bruni, Gherardi, \& Parolin, 2007) since it enables the interaction between human and non-human elements of the organization, beyond the articulation of a fragmented system of knowledge that is dispersed but while connected between employees, suppliers and customers. 
In this sense, technology plays a role in representative ways to organize, learn and mean the organization and the work itself. In the case of LCA is these technologies that enable constant interaction between members of the organization as well as contributes to the management of the three stores are physically distant.

Another point of great importance in the role of technology in everyday use of LCA is not only the interactions among its members, but especially in contact with suppliers that are made almost exclusively through technological mediation, as well as with a significant number of customers.

An interesting sign on the role of internet and ICT in the daily work of the company, observed in field research, was not heard the phones ring frequently, once or customers were in store for personal care (physical interaction ) or were being addressed by email, MSN or Skype (interaction mediated by technology). The eventual use of the telephone and the radio was used for communication between officials of the LCA was fired a few times during the day, as compared to the use of email and MSN. Employees who used the radio were more members and the courier, the latter by reason of not working in front of a computer.

From the considerations so far about the influence and role of technology in the LCA as a process of organizing the need arises to lead the reader in order to understand how it was my reflection and interpretation of what is proper to the LCA using the technology in regarding this process, as well as what is the relationship between this and PBS and ethnomethodology. To expose what I consider as a response to this statement, I believe it is important to resume a major speech by Mr. José in the interview when he says: "At LCA we do not focus much on that management of working time, we look for more productivity ... than whether the guy ... and people seeking more productivity, the numbers ...". This excerpt highlights something that is characteristic of LCA, i.e., its focus on results from the work of people and not the rigor of a standardized work process and where it is performed.

For partners, the key is that employees use the tools available at the company in order to perform the activity, the sale of tourist products and services. In this sense, the confidence of shareholders, as well as the other employees in the efficiency that technology provides for organization and completion of work is justified to some extent, the speech of Mr. José in the control of officials.

This position is justified aesthetically when taken as a basis for objects (in this case technology) for more practical as they are, are rarely separated from their symbolic meaning and power existing in them and as a symbol, the objects are able to touch sensations, feelings and reasons for action. In other words, the technology meant for members, control and power over the shares of LCA, something recognized by officials that while the technology also had a symbol of freedom in flexible working hours. During the field research on LCA was possible to see that this idea on the easing of the workload is spread among members of the organization and with concrete actions regarding the work shift, and it was common for people to negotiate their work schedules, as well as their days off, without losing sight of the calls that needed to be made. 
This situation seems to indicate that employees take the hybrid reported by Valtonen (2009) in relation to the mixture of working time with free time, as well as the fact that the workplace be on both the physical space of the company as at the homes of employees. Although it is considered that the organizing (Gherardi, 2006; Czarniawska, 2008), in the context of LCA, took this condition due to the adoption of technology is fundamental to point to other concepts that seem to contribute greatly in explaining this process. One is the Garfinkelian trust (Garfinkel, 2006; Rawls, 2008) in the opinion of this firm's partners that people were decent and competent to perform the work and deserved to be part of that company. From this point of view we can say that in the studied environment officials did not earn the confidence of the chiefs, but they lost when their actions manifest did not align with the "spirit" of the LCA, which can be called "committed to freedom results."

To demonstrate confidence in the LCA, I describe two different situations. The first refers to the hiring and trajectory of a store supervisor for the VM. With less than a month in the LCA, he was working alone in the store when the scale was well planned. This caused him to have possession of a copy of the key store, as well as access to cash for the day labor in cash. The second situation occurred when there was a resignation of one of the employees because of the finding of many evil actions done on purpose. In one of the officer issued a ticket with wrong date because he failed to maintain the value promised to the client, and not to lose the sale, made the issue with the previous day's date. On another occasion she got hold of backpacks for travel as a supplier to the store to be sent to customers who purchase a certain kind of travel package. These two examples represent the confidence shown in the social relations established in the LCA.

Another concept that also aids in understanding the process of organizing the LCA is the taste-making (Gherardi, 2009b). Revealing situations this process came when it was observed that the discourse constructed by the company when it comes to serving customers "effectively" was reflected in the collective behavior in relation to working hours, as well as the use of technology, ie the refinement of how to organize working time among members of the LCA, as this process was based on the use of technology represented the collective action of taste-making. This process of taste-making was supported by the collective creation of an aesthetic judgment LCA (Strati, 1992, 1999, 2007, 2009, Gherardi, 2009b) which is the result of negotiations everyday aesthetic of all members of the LCA. The process of organizing the LCA seen as a social context that directs the eye to the use of technology in this process is interpreted as an expression of everyday life of the company, arising from the manifestations of individual and collective actions of the members built on an aesthetic perspective. The organizing of the LCA is by no means formal, i.e. is built on the act tacitly negotiated between all its members in everyday life, a situation that enhances the sensory faculties and the influence of aesthetics in this process. However, it is worth mentioning that the process of organizing the LCA substantially influence other processes within the company, especially with regard to that core business is sales of tourism products and services and management's own LCA as a whole. 


\section{FINAL REMARKS}

The use of technology as a travel agency in practice involves a sensory knowledge (Strati, 2007) result of a continuous process of collective learning among members of the company researched and the artifacts found there. Among them we highlight the computers that take the condition of social actors (Bruni, 2005, Suchman et al., 1999) allow the creation of an aesthetic judgment (Strati, 1992, 2007, 2009) in relation to its use by members of LCA.

Thus, the everyday act searched around the practice establishes a process of learning-inpractice and knowing-in-practice (Gherardi, 2006) from which this practice is produced, reproduced and changed the day-to-day as members will be appropriating it and making the tastemaking (Gherardi, 2009b) that enables its refinement.

Added to this is important to strengthen the process of collective learning is supported in organizing (Gherardi, 2006; Czarniawska, 2008), implying that members assume the condition of artifacts and social actors and technology acquires status of social practice (Suchman et al. 1999; Bruni, 2005). Thus the interaction that promotes the technology allows that there is a movement of knowledge that involves not only the actors of the agencies surveyed, but their customers and suppliers that integrate a fragmented system of knowledge of travel in which each player in their interaction with each other contribute to this process (Bruni, Gherardi, \& Parolin, 2007).

The process of learning to use technology as practice in the travel agency company studied seems to be directly related to the dynamics of current tourism market in which, to reduce costs and improve service distribution, airlines, hotels, car rental companies, travel insurance companies and tour operators offer their products and services through the internet both to travel agents as well as to end consumers. The provision of such service is done, so that companies may have physical and virtual resources for serving customers. Thus, the agency in its daily life is required to learn how their suppliers' systems and ways of organizing work, as well as learn to sell services based on the demands of customers who already have lots of information about what they are going to buy before arriving at the agency. It is up to the staff to develop ways to articulate all the information and products on the market and transform the tourist trade language in appropriate options to the customer needs.

Thus, the process of collective learning at the travel agency is based on the responses that the organization needs to give to the customers' demands, as well as in the appropriation of service acquisition from providers, both situations are always set with the need to use information and communication technologies to merge into the knowledge that can be named travel chain, in which the travel agency is the intermediary and, as an organization, needs to offer its customers travel solutions that are the result of an alignment between the customers' need with the available suppliers' services. This ability to coordinate services to meet a customer demand is configured as a tacit knowledge and is learned through an aesthetic way (Strati, 2007), in which the experience of those working plus the use of their senses to interpret each situation and the singularities of the field, which allow this form of organizing. 
The use of technology as a practice is used both by the travel agency, as by customers and suppliers to establish the travel process while knowing-in-practice (Gherardi, 2006), in which everyone - travel agency, customers and suppliers - act influenced by the possibilities offered by technology so that this practice establishes itself as a practice that goes beyond the agency itself and is consolidated among those involved in the travel chain. Recognizing that organizations are composed of human and non-human elements, especially with the advent of new information and communication technologies leads to the understanding of the workplace as fragmented systems of knowledge (Bruni, Gherardi, \& Parolin, 2007) in which people, symbols, and technologies work together to build and rebuild the social understanding and organizational action.

The practice of using technology in a process of reflection and action (Garfinkel, 2006; Gherardi, 2006) changed even the way in which the travel agency studied is organized, for instance, there are three employees that do a telecommuting activity, they work at home because their work can be done without a physical presence in the travel agency, they work with finances and marketing activities. Thus, only the ones who work directly with sale are inside the stores. This situation represent how an organization reassembling itself facing the new possibities produced by the technologies and points out that the way of organizing is not only physical and human centered, but virtual and non-human composed too (Bruni, 2005, Bruni, Gherardi, \& Parolin, 2007).

Finally the use of PBS and ethnomethodology to comprehend the learning, knowing and organizing processes and the use of technology as practice in travel agencies can contribute in two main aspects: (1) foment theoretical and methodological approach to tourism area, especially in managent; (2) points out the reassembling of travel agencies influenced by the development of technologies, principally those related with internet, that produce new forms of work and consume tourism.

As a suggestion for future investigations it is understood that it would be interesting to widen the scope of research to deepen understanding of technology use as a practice by customers and suppliers in the chain of travel to check the mutual influence of these agents in the process of collective learning.

\section{REFERENCES}

Bruni, A., Gherardi, S., \& Parolin, L. L. (2007). Knowing in a System of Fragmented Knowledge. Mind, Culture, and Activity, 14(1-2), 83-102.

Bruni, A. (2005). Shadowing Software and Clinical Records: On the Ethnography of Non-Humans and Heterogeneous Contexts. Organization, 12(3), 357-378

Coulon, A. (2005). La Etnomedotología (3a ed). Madrid: Cátedra.

Czarniawska, B. (2008). Organizing: how to study it and how to write about it. Qualitative Research in Organizations and Management: An International Journal, 3(1), 4-20. 
Francis, D., \& Hester, S. (2004). An Invitation to Ethnomethodology: language, society and interaction. London: Sage.

Garfinkel, H. (2006). Studios en Etnometodología. Barcelona: Anthropos.

Gherardi, S. (2009b). Practice? It's a Matter of Taste! Management Learning, 40(5), 535-550.

(2009a). Introduction: the critical power of the "practice lens". Management Learning, 40(2), $115-128$.

(2006). Organizational Knowledge: The Texture of Workplace Learning. Oxford: Blackwell Publishing.

(2001). From organizational learning to practice-based knowing. Human Relations, 54(1), 131-139.

(2000). Practice-based theorizing on learning and knowing in organizations, Organization, 7(2), 211-

223.

Gherardi, S., \& Nicolini, D. (2001). The Sociological Foundations of Organizational Learning. In M. Dierkes, et al. (Org.) Organizational learning and knowledge (pp. 35-60). Oxford: Oxford University Press.

Hatch, M. J., \& Yanow, D. (2003). Organization theory as an interpretative science, in H. Tsoukas and C. Knudsen (Eds.) The Oxford Handbook of Organization Theory (pp. 63-87). Oxford: Oxford University Press.

Hatch, M. J. (1997). Organization Theory: modern, symbolic and postmodern perspectives. Oxford: Oxford University Press.

Hilbert, R. (1990). Ethnomethodology and the micro-macro order. American Sociological Review, 55, 794808.

Maynard, D., \& Clayman, S. E. (1991). The diversity of ethnomethodology. Annual Review of Sociology, 17, 385-418.

Nicolini, D. (2010a). Medical Innovation as a Process of translation: a case from the field of Telemedicine, British Journal of Management, 21(4), 1011-1026.

(2010b). "Practice as the Site of Knowing: Insights from the Field of Telemedicine", Organization Science, published online, 2010b. Available in <http://orgsci.journal.informs.org/cgi/content/abstract/orsc.1100.0556v1> (acess on 6th February 2011). 212. (2009) Articulating Practice through the Interview to the Double. Management Learning, 40(2), 195-

Nicolini, D., Gherardi, S., \& Yanow, D. (2003). Introduction: Toward a practice-based view of knowing and learning in organizations. In D. Nicolini, S. Gherardi , \& D. Yanow (Orgs.) Knowing in organizations: a practicebased approach (pp. 3-31). New York: M. E. Sharpe.

Rawls, A. W. (2008). Harold Garfinkel, Ethnomethodology and Workplace Studies. Organization Studies, 29(5), 701-732.

Psathas, G. (2004). Alfred Schutz's influence on American sociologists and sociology. Humam Studies, 27(1), $1-35$.

Romero, J. J. C. (1991). Etnometodologia: una explicación de la construcción social de la realidad. Reis, 56, 83-114.

Sandelands, L., \& Srivatsan, V. (1993). The Problem of Experience in the Study of Organizations. Organization Studies, 14(1), 01-22.

Strati, A. (2009). "Do You Do Beautiful Things?" Aesthetics and Art in Qualitative Methods of Organization Studies. In D. Buchanan, \& A. Bryman (Eds.). The Sage Handbook of Organizational Research Methods (pp. 230-245). London: Sage. 
(2007). Sensible Knowledge and Practice-based Learning. Management Learning, 38(1), 61-77. . (1999). Organization and Aesthetics. London: Sage.

(1992). Aesthetic understanding of organizational life. Academy of Management Review, 17(3), 568581.

Suchman, L. et al. (1999). Reconstructing technologies as social practice. American Behavioural Scientist, 43(3), 392-408.

Ten Have, P. (2004). Understanding Qualitative Research and Ethnomethodology. London: Sage.

UNWTO (2010). World Tourism Barometer, 8(3). Available in

<http://www.unwto.org/facts/eng/pdf/barometer/UNWTO Barom10 3 en excerpt.pdf $>$ access on 8th january 2012.

Valtonen, A. (2009). Small tourism firms as agents of critical knowledge. Tourist Studies, 9(2), 127-143.

Received: $30 / 05 / 2012$

Approved: 11/07/2012. 